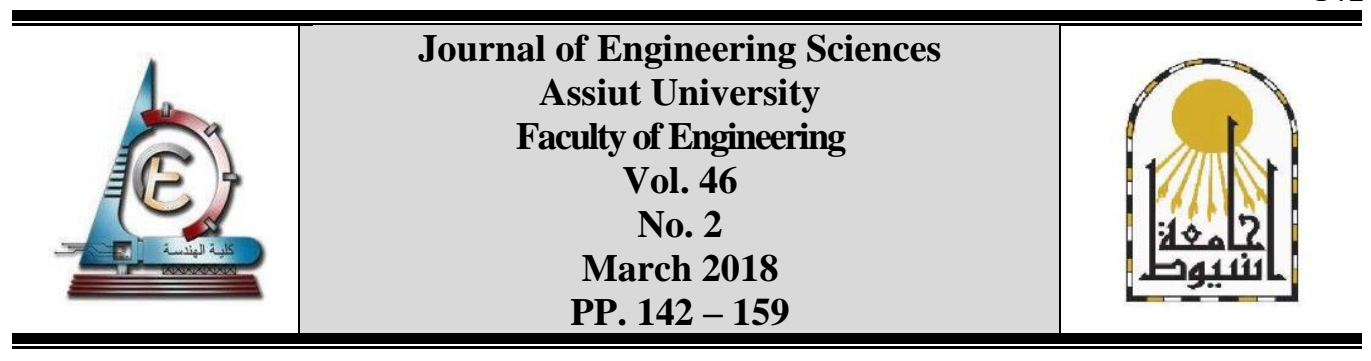

\title{
IMPROVEMENT OF THE CONCRETE CHARACTERISTICS BY USING SUGAR INDUSTRY WASTES (VINASSE)
}

\author{
A. Megahed Ahmed, Mohamed M. A, Omar A, F. and Shawky M. H. \\ Civil Engineering Depart. Faculty of Engineering, Assuit University, Assuit, Egypt.
}

Received 21 November 2017; Accepted 31 December 2017

\begin{abstract}
The current study is concerning with the effect of adding (VSW 2016) to the concrete properties for both fresh and hardened states, concerning of maximizing the benefits from the vinasse liquid, which is produced in Egyptian Sugar \& Integrated Industries Company (ESIIC). This is due to the fact that vinasse is by a-product from fermentation and distillation of the Molasses liquid which is the sugar industry product. Vinasse liquid is a secondary product of sugar industry. It consists of mixture from water, organic material and inorganic slats. Some pre-experiments have been carried out on the (VSW 2016) liquid as a plasticizer for mixtures of cements. It was proved from primary results that the (VSW 2016) solution has improved the consistency characteristics and compressive strength of concrete. These results are considered promising results for cement mixtures in general and encouraged continuing the detailed studies to assure the efficient use of (VSW 2016) addition in different applications of building and housing works. Therefore, the main purpose of this research is to study experimentally the mechanism effect of suggested admixture (VSW 2016) on concrete characteristics.
\end{abstract}

\section{Introduction}

Molasses is by a-product of sugar industry, which uses cane sugar or beet sugar. Vinasse liquid is a secondary product from the processes of distillation and fermentation of molasses liquid which consider an integrated industries to produce Ethyl Alcohol, dry yeast and Acetone, whether cane sugar molasses or beet sugar molasses. The use of vinasse in the application of concrete is unavailable in open literature. A research was done to study the effect of diluted vinasse (7-12\%) on concrete mixing in fresh and hardened phase [1] .The results showed a clear increase in compression strength and tensile strengths (splitting strength, flexural strength) compared to the mixing control. Usage of molasses in concrete as a water reducing and retarding admixture [2, 3] was emphasizes and comparison is made between molasses with $40 \%$ purity grade and Lignsulphonate with respect to improvements in properties of concrete and the results are: Usage of molasses as a plasticizer in concrete is satisfying the American Society for Testing and Materials (ASTM C494-98) stand for water reduction criteria and can be used as a type D and by reducing the dosage it can be used as type A. But usage of Lignosulphonate and molasses based plasticizer causes the reduction of the coefficient of capillary due to increase in setting times as well as decrease in $\mathrm{W} / \mathrm{C}$ ratio, but molasses are more effective on reducing of capillary coefficient than Lignosulphonate. 
The previous researches handling the use of sugar, sugar cane juice, jaggery and molasses from sugar cane or sugar beet on physical and mechanical properties of cement paste and concrete. Because sugar, carbohydrate derivatives and some salts exhibit retarding action and plasticizing properties in concrete [4, 5]. Chemical admixtures improved the concrete workability and reduced the total amount of mixing water needed to compensate for slump loss. The reduction in mixing water was a function of the admixture dosage; the higher the dosage, the higher the reduction in the mixing water [6]. Super plasticizers, also known as plasticizers, include water - reducing admixtures compared to what is commonly referred to as a "water reducer " or " mid- range water reducer ", super plasticizers are" high - rang water reducers". High range water reducers admixtures that allow large water reduction or greater flow ability (as defined by the manufacturers, concrete suppliers and industry standards) without substantially slowing set time or increasing air entrainment. Each type of super plasticizer has defined ranges for the required quantities of concrete mix ingredients, along with the corresponding effects. Sherif A.M. Khafaga [7] found that all types of chemical admixture used are effective in increasing the initial slump and reducing the rate of slump loss. However, high - range and retarding admixture (type $\mathrm{G}$ ) gives the most effecting performance in the 30 minutes after casting, while, the retarding admixture (type B) gives better performance beyond first 30 minutes. Collepardi M. [8] studied the placing characteristics of concrete can be enhanced by using plasticizing and super plasticizing admixtures without any change in the water cement ratio with respect to the plain mixture. As it was found for super plasticizing admixtures, the polymer adsorption, rather than the electrostatic repulsion, is responsible for the dispersion of large agglomerates of cement particles into smaller ones, which results in a remarkable the fluidity of cement mixes. A.Megahed et al [9] studied effect of super plasticizers on concrete characteristics. Modern production of high concrete is closely connected with wide using of different types of chemical traditional admixture, which in small doses allow obtaining the required physical and technical properties of concrete. Using type $\mathrm{F}$ and type $\mathrm{G}$ admixtures had a positive effect on the concrete properties for all concrete mixes contain blended cements; it had negative effect on the air content for mixes [10]. Ravi Kumar et al [11] showed that coal bottom ash absorb less water up to mix with $(0.01 \%$ sugar cane molasses and $20 \%$ age of coal bottom ash) and water absorption increase afterward. Sugar cane molasses contribute significantly in initial setting time and water absorption. M.Dheenadhayalan et al [12] conclude that sugar cane juice (SCJ) retarded the setting time of concrete. The workability, compressive strength and tensile strength of the concrete initially decreased the content of (SCJ) was increased at an optimum (SCJ) content $5 \%$. Amaziah et al [13] observed that 1- (SCJ) retarded the setting time and workability was reduced by the addition of (SCJ). 2- Compressive strength of the concrete initially decreased as the content of (SCJ) increased, at an optimum (SCJ) content $10 \%$, the compressive strength started to increase as the (SCJ) was increased but reduction occur due to partial replacement of water with (SCJ).

\section{Experimental work}

\subsection{Techniques of preparing and producing the suggested admixture [VSW2016] liquid}

The experimental technique for preparing and producing the suggested admixture [VSW2016] liquid was carried out by adding the concentrated vinasse [35\%] to Sodium Naphatalene Formaldehyde (SNF) and mixed them with mechanical mixer, then added the mixer to pure water and mix them with mechanical mixer, then add Miargal V6 and mix 
JES, Assiut University, Faculty of Engineering, Vol. 46, No. 2, March 2018, pp.142-159

them until obtaining homogenous solution (VSW2016). Then, the compositions of components of (VSW2016) are the following:-

1-Addition of concentrated vinasse liquid (35\%) which produced at (ESIIC) add with (20\%) from total admixture mix which used at the current study. Table no. 1 shows the results of chemical analysis of concentrated vinasse $(35 \%)$

2 - Sodium Naphatalene Formaldehyde (SNF) liquid (40\%) which produced at coke company or at straa company (one of Al kharafi companies group at sity of 10 Ramadan) add with $28 \%$ from total admixture mix. Table no. 2 shows the results of chemical analysis of Sodium Naphatalene Formaldehyde (SNF).

3- Pure water at $51.8 \%$ 4- Miargal V6 which produced at somral Company add with $0.2 \%$ from total admixture mix to stop action of Bacteria. From the above trails the correlation of components of the proposed Admixture [VSW2016] by weight from the solid particles are shown in table no. 3. Table no.4 shows the results of chemical analysis of suggested admixture (VSW2016).

Table 1.

Chemical analysis of concentrated vinasse $(35 \%)$

\begin{tabular}{|c|c|c|c|}
\hline Parameter & Value & Parameter & Value \\
\hline Density $\left(\mathrm{gm} / \mathrm{cm}^{3}\right)$ & 1.135 & Ash \% gm & 6.68 \\
\hline $\mathrm{PH}$ & 5.00 at $23{ }^{\circ} \mathrm{C}$ & $\mathrm{P}_{2} \mathrm{O}_{5} \mathrm{gm}$ & 0.219 \\
\hline Solid past \% gm & 35.13 & $\mathrm{C}_{\mathrm{a}} \mathrm{O} \mathrm{gm}$ & 1.44 \\
\hline Nitrogen \% gm & 0.83 & $\mathrm{M}_{\mathrm{a}} \mathrm{O}$ & 0.58 \\
\hline Protein \% gm & 5.18 & Chloride $(\mathrm{C} 1)$ & 2.08 \\
\hline Total sugar \% gm & 5.48 & & \\
\hline
\end{tabular}

Table 2.

Chemical analysis of Sodium Naphatalene Formaldehyde (SNF)

\begin{tabular}{|c|c|c|c|}
\hline Parameter & Value & Parameter & Value \\
\hline Solid content $(\% \mathrm{wt})$ & $92.0-94.0$ & Ionic nature & Anigic \\
\hline $\begin{array}{c}\text { Sulphate content }(\% \mathrm{wt}) \\
\left(\text { as } \mathrm{So}_{4}^{-2}\right)\end{array}$ & $5.00-7.00$ & Solubility & $\begin{array}{c}\text { Soluble in hard \& } \\
\text { soft water }\end{array}$ \\
\hline Bulk density $\left(\mathrm{gm} / \mathrm{cm}^{3}\right)$ & 0.65 & Appearance & Light brown powder \\
\hline Chloride $(\mathrm{ppm})$ as CI & $650 \mathrm{max}$ & PH of $10 \%$ solution & $7.00-9.00$ \\
\hline
\end{tabular}

Table 3.

Correlation of components of the suggested admixture (VSW2016)

\begin{tabular}{|c|l|c|}
\hline $\begin{array}{c}\text { Type of } \\
\text { admixture }\end{array}$ & \multicolumn{1}{|c|}{ Components of the admixture\%by weight } & $\begin{array}{c}\text { Correlation of } \\
\text { components }\end{array}$ \\
\hline \multirow{4}{*}{$\begin{array}{c}\text { VSW2016 } \\
\text { (suggested) }\end{array}$} & $\begin{array}{l}\text { 1- Concentrate vinasse 35\% (By a- product from } \\
\text { distillery factories)brown liquid solution }\end{array}$ & $20 \%$ \\
\cline { 2 - 3 } & 2- Sodium Naphatalene Formaldehyde & $28 \%$ \\
\cline { 2 - 3 } & 3- Pure water & $51.8 \%$ \\
\cline { 2 - 3 } & 4- Mirgal v6 & $0.2 \%$ \\
\hline
\end{tabular}


Shawky M. H. et al., Improvement of the concrete characteristics by using sugar industry wastes .....

Table 4.

Chemical suggested admixture [VSW2016] (Tested by Analytical Chemistry Unit ACAL Assiut University)

\begin{tabular}{|c|c|c|c|}
\hline Parameter & Value & Parameter & Value \\
\hline P.H & 8.20 at $23^{\circ} \mathrm{C}$ & Total sugar & $0.49 \%(\mathrm{wt} / \mathrm{wt})$ \\
\hline Sulfate & $7.75 \%(\mathrm{wt} / \mathrm{wt})$ & Chloride & $0.8 \%(\mathrm{wt} / \mathrm{wt})$ \\
\hline
\end{tabular}

\subsection{Concrete}

The tested specimens were casted using three batches of normal strength concrete (NSC) .The physical and mechanical properties of the material contents used to form the batches are discussed in this section.

\subsubsection{Fine aggregate (sand)}

Clean and round fine aggregate was used. The sand was washed and dried in open area before use. The sand grading was maintained by using sieves according to ECP (Egyptian Code of Practice No 203, 2001). Very fine material was excluded from the mixture by using fine sieves. Fig 1 shows sand sieve analysis.

\subsubsection{Course aggregate (gravel)}

Round well- graded and clean gravel was used in the mixture with maximum nominal size $37.5 \mathrm{~mm}$. The gravel was found more suitable to be used as coarse aggregates. It has a rougher texture and its surface is irregular. The gravel was washed using potable water to ensure the removal of dust or impurities that might exist. Fig no. 2 shows gravel sieve analysis. The characteristics of used aggregate are shown in table no.5

Table 5.

Physical, mechanical and chemical properties of used aggregate.

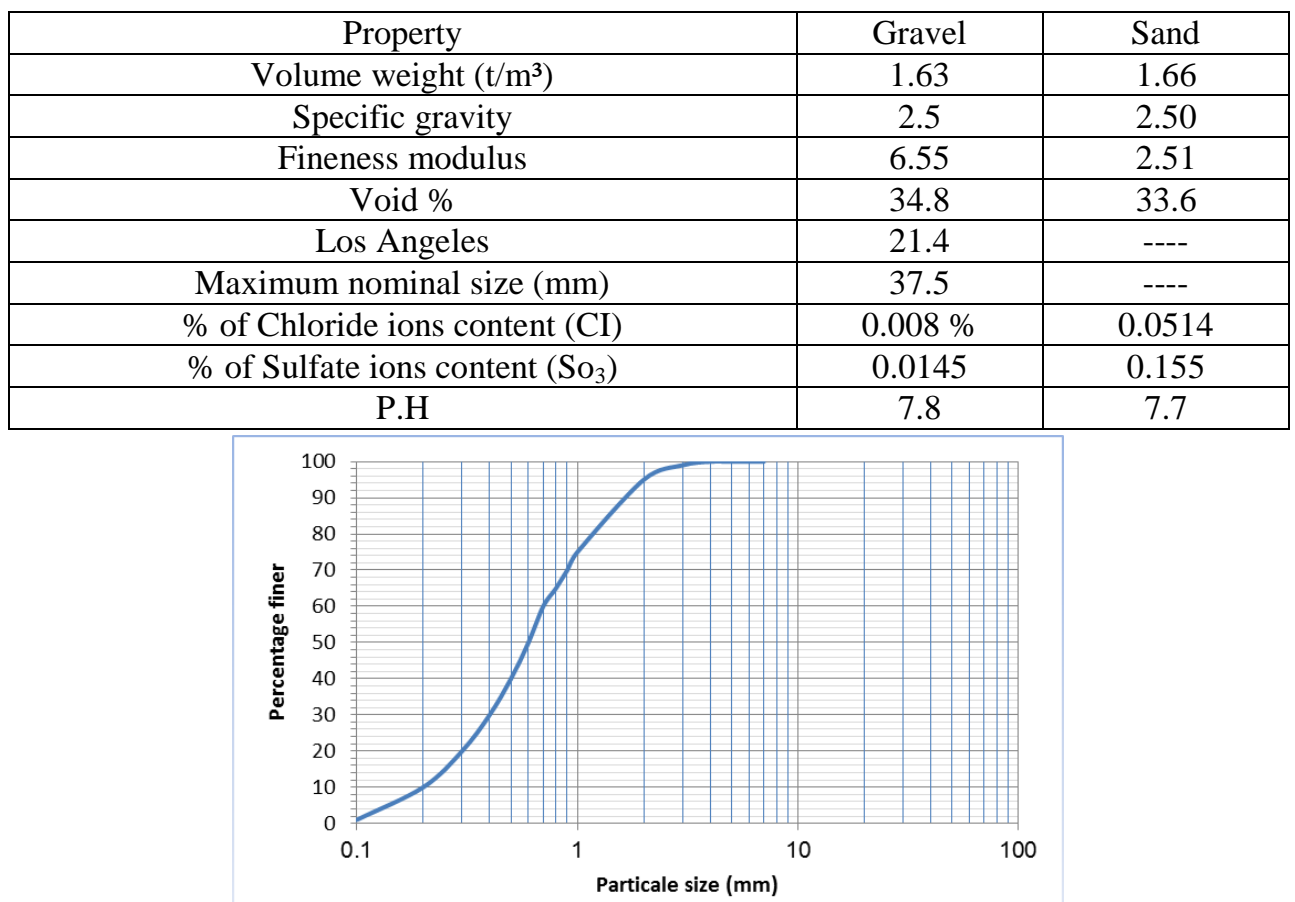

Fig. 1. Sand sieve analysis. 


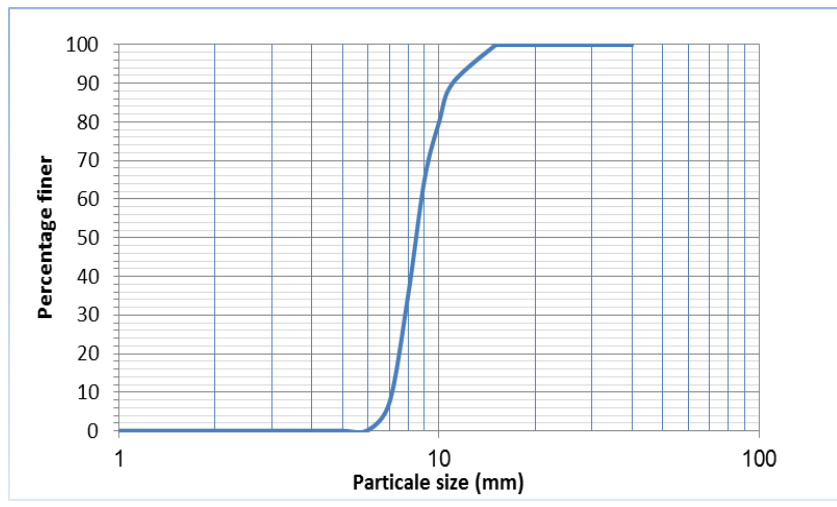

Fig. 2. Gravel sieve analysis

\subsubsection{Cement}

Ordinary Portland cement (Assiut cement) was used throughout the program for making concrete. The fineness degree, initial and final setting times and the mortar compressive strength were measured according to Egyptian Code of Practice (ECP 203-2007). The test results of the cement sample are shown in table no. 6

\section{Table 6.}

Test results of ordinary Portland cement (Assiut cement).

\begin{tabular}{|c|c|c|c|}
\hline \multicolumn{2}{|l|}{ Parameter } & Value & ESS no.203-2007 \\
\hline \multicolumn{2}{|c|}{$\%$ of Retained on Sieve No. 170} & 4.7 & $>/ 10$ \\
\hline \multicolumn{2}{|c|}{ Initial setting times (min) } & 73 & $\geq 45$ minutes \\
\hline \multicolumn{2}{|c|}{ Final setting times (min) } & 217 & $<10$ hours \\
\hline \multirow{2}{*}{ Mortar compressive Strength (MPa) } & 3 days & 19.55 & $\geq 18 \mathrm{~N} / \mathrm{mm}^{2}$ \\
\hline & 7 days & 29.14 & $\geq 27 \mathrm{~N} / \mathrm{mm}^{2}$ \\
\hline \multicolumn{2}{|c|}{ Soundness (le chotelier) } & $1 \mathrm{~mm}$ & $<10 \mathrm{~mm}$ \\
\hline \multicolumn{2}{|l|}{ Specific gravity } & 3.15 & ---- \\
\hline
\end{tabular}

\subsubsection{Water}

Potable water was used in the mixes. Chemical analysis of such water showed that it was suitable for the used cement to allow for full hydration.

\section{Test results and discussion}

\subsection{Mix design}

The mixes used to cast the specimens were developed by batching in C.R.L (Concrete Research Laboratory) at Assiut University. The details of the different mixes are as follows:-

\subsubsection{Normal strength concrete}

In this experimental study, three different normal - strength concrete mixes were used. Trial mixes were conducted to reach the target cubic compressive strength of 20, 30 and 35 MPa after 28 days. Table no.7shows mix proportion by weight of the quantities needed for one cubic meter of concrete to achieve the target cubic compressive strength used [VSW2016] additive. Table no.8 shows mix proportion by weight of the quantities needed for one cubic meter of concrete to achieve the target cubic compressive strength used Addcrete BVS additive 
Shawky M. H. et al., Improvement of the concrete characteristics by using sugar industry wastes .....

Table 7.

Concrete mixtures detailed used [VSW2016] additive

\begin{tabular}{|c|c|c|c|c|c|}
\hline \multirow[b]{2}{*}{$\begin{array}{c}\text { Type\& Percentage of } \\
\text { admixture }\end{array}$} & \multicolumn{5}{|c|}{ Composition of concrete mixture } \\
\hline & $\begin{array}{c}\text { [VSW2016] } \\
\text { Liter/m³ }\end{array}$ & $\begin{array}{c}\text { Water } \\
\text { Liter } / \mathrm{m}^{3}\end{array}$ & $\begin{array}{l}\text { Gravel } \\
\mathrm{Kg} / \mathrm{m}^{3}\end{array}$ & $\begin{array}{l}\text { Sand } \\
\mathrm{Kg} / \mathrm{m}^{3}\end{array}$ & $\begin{array}{l}\text { Cement } \\
\mathrm{Kg} / \mathrm{m}^{3}\end{array}$ \\
\hline Control mix (c) & ----- & 175 & \multirow{4}{*}{1265} & \multirow{4}{*}{645} & \multirow{4}{*}{300} \\
\hline $1.5 \%[$ VSW2016] & 4.5 & 153 & & & \\
\hline $2.0 \%[$ VSW2016] & 6.0 & 145 & & & \\
\hline $2.5 \%[\mathrm{VSW} 2016]$ & 7.5 & 138 & & & \\
\hline Control mix (c) & ----- & 180 & \multirow{4}{*}{1256} & \multirow{4}{*}{635} & \multirow{4}{*}{350} \\
\hline $1.5 \%[$ VSW2016] & 5.25 & 150 & & & \\
\hline $2.0 \%[$ VSW2016] & 7.0 & 142 & & & \\
\hline $2.5 \%[$ VSW2016] & 8.75 & 135 & & & \\
\hline Control mix (c) & ----- & 190 & \multirow{4}{*}{1216} & \multirow{4}{*}{615} & \multirow{4}{*}{400} \\
\hline $1.5 \%[\mathrm{VSW} 2016]$ & 6.0 & 145 & & & \\
\hline $2.0 \%[\mathrm{VSW} 2016]$ & 8.0 & 140 & & & \\
\hline $2.5 \%[$ VSW2016] & 10.0 & 132 & & & \\
\hline
\end{tabular}

Table 8.

Concrete mixtures detailed used Addcrete BVS additive

\begin{tabular}{|c|c|c|c|c|c|}
\hline \multirow[b]{2}{*}{$\begin{array}{l}\text { Type\& Percentage of } \\
\text { admixture }\end{array}$} & \multicolumn{5}{|c|}{ Composition of concrete mixture } \\
\hline & $\begin{array}{c}\text { Addcrete BVS } \\
\text { Liter } / \mathrm{m}^{3}\end{array}$ & $\begin{array}{c}\text { Water } \\
\text { Liter } / \mathrm{m}^{3}\end{array}$ & $\begin{array}{l}\text { Gravel } \\
\mathrm{Kg} / \mathrm{m}^{3}\end{array}$ & $\begin{array}{c}\text { Sand } \\
\mathrm{Kg} / \mathrm{m}^{3}\end{array}$ & $\begin{array}{l}\text { Cement } \\
\mathrm{Kg} / \mathrm{m}^{3}\end{array}$ \\
\hline Control mix (c) & ----- & 180 & \multirow{4}{*}{1256} & \multirow{4}{*}{635} & \multirow{4}{*}{350} \\
\hline $1.5 \%$ [Addcrete BVS] & 5.25 & 150 & & & \\
\hline $2.0 \%$ [ Addcrete BVS] & 7.0 & 142 & & & \\
\hline $2.5 \%$ [ Addcrete BVS] & 8.75 & 135 & & & \\
\hline
\end{tabular}

\subsection{Mixing, Casting and Curing}

At first the concrete mixture components has been measured by weight and the (VSW2016) addition has been mixed with mixing water in percentage of cement, and the mixing processes is being followed:

Large aggregate has been mixed with sand in a drum mixer for about two minutes, then cement has been added and the mixer is kept in rotation until reaching a reasonable degree of homogeneity, then the mixing water be added [for control mixture] or (VSW2016) and water mixing [for (VSW2016) mixtures] during the mixer rotation with continues mixing for about four minutes

After finishing of mixing processes, the fresh concrete tests are started, at the same time the hardened concrete tests are stated after different times of curing in water by using clean $(15 \times 15 \times 15 \mathrm{~cm})$ cube steel forms, clean $(10 \times 10 \times 50 \mathrm{~cm})$ beam steel forms and clean $15 \mathrm{~cm}$ diameter $\times 30 \mathrm{~cm}$ length cylinder steel forms cast from each concrete batch. The concrete cubes, cylinders and beams were tested. Compressive strength, indirect tensile strength (splitting - flexural) was taken as the average of three specimens of cubes, cylinders and beams.

All mixtures achieve a plastic consistency, the slump value is kept in the range of [100120] mm which it's suitable for most applications of reinforcement concrete. Due to the 
practical results of measuring, the percentage of ( water / cement ) has been determined for control mixtures equal ( $0.58,0.51,0.48$ ), for cement contained [ $300,350,400$ ] $\mathrm{kg} / \mathrm{m}^{3}$ in series . In terms of mixtures contains (VSW2016) addition, the water quantity for mixing is lowered in comparison with the control mixtures as the slump value is kept as basic for comparing the effect of (VSW2016) addition on the performance of concrete mixtures. After finishing of mixing processes, the fresh concrete tests are started, at the same time the special samples has been poured with the test of mechanical, physical properties and durability test.

A detailed study has been carried out to show the [VSW2016] addition effect on the concrete mixture in three different inclusions from cement $\left[300 \& 350 \& 400 \mathrm{~kg} \backslash \mathrm{m}^{3}\right]$ to produce several grades of concrete covers a wide range of applications.

For each concrete mixture [for every cement inclusion] the [VSW2016] addition has been added in three different inclusions from cement weight and they are:-

- $[1.5 \%, 2.0 \%, 2.5 \%]$ and thus a concrete mixtures have been poured for every cement inclusion. Three of them include [VSW2016] addition and the fourth is a mixture for control without [VSW2016] addition for the purpose of comparing the effect of using [VSW2016] on the concrete mixtures. Also we use commercial admixture like Addcrete BVS which produced by Chemicals for Modern Building ( CMB ), where used as a liquid that water reducing high range and retarding according to ESS 1899$1 / 2006$ to compare the effect of using [VSW2016] on the concrete mixtures with the effect of addcrete BVS.

- Casting of 18 concrete mixtures for every mixture and the basic properties has been measured on the fresh state and some of the mechanical and physical properties on the hardened state and also some of the durability properties have been measured after the concrete is reaching enough resistance at the age about 28 days. About 291 cubes, 180 beams and 180 cylinders were casted and tested according to the following:-

3.3. Tests

\subsubsection{Basic properties at the fresh state}

A fresh concrete test has been performed in parallel to determine some of the basic properties and it is following:

- The consistency by slump test (ESS 1988-1658)

- The setting time for initial and finally (ECP 203-2007)

- The air entraining by pressure method (ECP 203-2007) to determine the air entraining which is trapped and inside the concrete except the air content inside partials aggregate voids which determine by other methods.

\subsubsection{Mechanical and physical properties at the hardening state}

Tests made to determine:

1- Compressive strength: at ages 7, 28, 90 and180 days

2- Indirect tensile strength:

- Splitting strength in terms of the specification requirement (ESS1899-2006/1) at ages 28, 90 and 180 days.

- Flexural strength a (criterion of flexural rupture): in terms of the specification requirement (ESS1899-2006/1) at ages 28, 90 and 180 days 
3- Drying Shrinkage (ESS1899-2006/1): It's a kind of volumetric changes accompanied with losing water from cementric medium after curing in water for 28 days, and then the specimens should get out the curing basing and left to the dried in the laboratory atmosphere.

\subsubsection{Durability properties}

Tests made to determine:

1- Permeability of liquids and depth of water penetration.

2- Deterioration of compressive strength as a result for exposing to solution [10\% Sodium Sulphate $\mathrm{Na}_{2} \mathrm{SO}_{4}$ ]

3- Deterioration of surface scaling and change of concrete colour a result for exposing to solution [10\% Sodium Sulphate $\mathrm{Na}_{2} \mathrm{SO}_{4}$ ].

4- Diffraction X-ray test [XRD], on some mixtures to study the mineral composition and to make sure that Ettringite which already being formed

\subsubsection{Chemical characteristics}

Tests made to determine:

1- Chemical analysis for (VSW2016) addition.

2- After crushing specimens of cubes which exposed to solution $\left[10 \% \mathrm{Na}_{2} \mathrm{SO}_{4}\right]$ at 6 months age, the chemical tests will made to determine chloride and suplate content

\subsection{Fresh concrete test results}

Table no. 9contains the results of tests for the concrete mixtures on the fresh state, heir the most important conclusion and evidence

\subsubsection{Consistency}

Consistency by slump test method a comparison is made to show the effect of (VSW2016) addition in terms of lowering the quantity of mixing water with respect to control mixture. Table no.9shows that reducing on the water quantity of mixing about 12.57 $\%$ to $21.10 \%$ at cement content $300 \mathrm{~kg} / \mathrm{m}^{3}$. It also reaches the value from $16.7 \%$ to $25 \%$ at cement content $350 \mathrm{~kg} / \mathrm{m}^{3}$ and from $23.7 \%$ to $30.5 \%$ at cement content $400 \mathrm{~kg} / \mathrm{m}^{3}$.

According to (ESS 1988-1658) the minimum water reduction is $12 \%$ in comparison with the control mixture. Table no. 10 shows that reducing that water quantity of mixing about 16.7 to $25 \%$ at cement content $350 \mathrm{~kg} / \mathrm{m}^{3}$ using addcrete BVS

\subsubsection{Setting times (initial and finally)}

According to the requirements of the (ESS1899-2006/1) in terms of water reducing, high range and retarding:

-Initial primary time $\geq$ control mix $+1: 30$ (hour: min) (ESS 1899-1/2006)

-Finally setting time $\leq$ control mix + 6:00 (hour: min) ESS 1899-1/2006

From the result tables no.9\& no.10, it is clear that all mixtures for both (VSW 2016) and addcrete BVS accordance with ESS1899 - 1/2006, at all (VSW2016) percentages at all cement contents

\subsubsection{Air-entraining}

According to the Egyptian standardization specification (ESS 1899 - 1/ 2006) in terms of the additives which_delaying the hardening / water reducing and also the additives delaying the hardening / high water reducing, air-entraining for test mixture reducing 
JES, Assiut University, Faculty of Engineering, Vol. 46, No. 2, March 2018, pp.142-159

which contain (VSW2016) $\leq 2.0 \%$ in volume more than the control mixture. From the results in tables no.9\& no. 10, it is clear that the results of setting times (initial - final) and air entraining for all mixtures in both (VSW 2016) addition and addcrete BVS addition accordance of specification requirements.

Table 9.

Test results of concrete mixtures of (VSW 2016) addition at fresh state

\begin{tabular}{|c|c|c|c|c|c|c|c|c|c|}
\hline \multirow{2}{*}{$\begin{array}{c}\text { Type \& } \\
\text { Percentage of } \\
\text { admixture }\end{array}$} & \multicolumn{2}{|c|}{$\begin{array}{c}\text { Air } \\
\text { entraining } \%\end{array}$} & \multirow{2}{*}{$\begin{array}{c}\text { Water } \\
\text { reduction } \\
\%\end{array}$} & \multicolumn{4}{|c|}{ Setting time ( hour : minute) } & \multirow{2}{*}{$\begin{array}{l}\text { Cement } \\
\text { content } \\
\text { (c.c) } \\
\mathrm{kg} / \mathrm{m}^{3}\end{array}$} & \multirow{2}{*}{$\begin{array}{c}\text { Limits } \\
\text { ESS1899-2006/1 }\end{array}$} \\
\hline & Result & Diff. & & Initial & Diff. & Final & Diff. & & \\
\hline Control mix (c) & --- & $-\cdots$ & -ב- & $5: 50$ & $-\cdots$ & $7: 50$ & $\cdots$ & \multirow{4}{*}{300} & \multirow{12}{*}{$\begin{array}{l}\text { For mixes containing } \\
\text { addition } \\
\text {-Water reduction: } \\
12 \% \text { at least } \\
\text {-Setting times: Diff. } \\
\text { about controlmix: } \\
\text {-Initial setting } \\
\text { At. Least } 1: 30 \\
\text {-Final setting } \\
\text { Not more } 6: 00 \text { later } \\
\text {-Air entraining } \\
\leq 2 \% \text { by volume about } \\
\text { control mix }\end{array}$} \\
\hline $1.5 \%$ [VSW2016] & $-\cdots$ & $-\cdots$ & 12.57 & $7: 35$ & $1: 45$ & $10: 40$ & $2: 50$ & & \\
\hline $2.0 \%$ [VSW2016] & $-\overline{---}$ & $-\cdots$ & 17.10 & $8: 20$ & $2: 30$ & $12: 25$ & $4: 35$ & & \\
\hline $2.5 \%$ [VSW2016] & -ב-- & --- & 21.10 & $11: 10$ & $5: 20$ & $13: 30$ & $5: 40$ & & \\
\hline Control mix (c) & 2.0 & --- & -ב-- & $5: 05$ & --- & $7: 20$ & -+- & \multirow{4}{*}{350} & \\
\hline $1.5 \%$ [VSW2016] & 2.2 & +0.2 & 16.7 & $7: 10$ & $2: 05$ & $9: 35$ & $2: 15$ & & \\
\hline $2.0 \%$ [VSW2016] & 2.1 & +0.1 & 21.1 & $7: 30$ & $2: 25$ & $9: 05$ & $1: 45$ & & \\
\hline $2.5 \%$ [VSW2016] & 1.8 & -0.2 & 25.0 & $8: 50$ & $3: 45$ & $10: 45$ & $3: 25$ & & \\
\hline Control mix (c) & $-\cdots$ & $-\cdots$ & $-\cdots$ & $5: 10$ & $\ldots$ & $7: 00$ & -- & \multirow{4}{*}{400} & \\
\hline $1.5 \%$ [VSW2016] & -- & -- & 23.7 & $6: 20$ & $1: 10$ & $8: 55$ & $1: 55$ & & \\
\hline $2.0 \%$ [VSW2016] & --. & - & 26.3 & $7: 20$ & $2: 10$ & $10: 40$ & $3: 40$ & & \\
\hline $2.5 \%$ [VSW2016] & 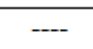 & -- & 30.5 & 9:00 & $3: 50$ & $12: 10$ & $5: 10$ & & \\
\hline
\end{tabular}

Table 10.

Test results of concrete mixtures of (Addcrete BVS) addition at fresh state

\begin{tabular}{|c|c|c|c|c|c|c|c|c|c|}
\hline \multirow{2}{*}{$\begin{array}{c}\text { Type \& } \\
\text { Percentage of } \\
\text { admixture }\end{array}$} & \multicolumn{2}{|c|}{$\begin{array}{c}\text { Air entraining } \\
\%\end{array}$} & \multirow{2}{*}{$\begin{array}{c}\text { Water } \\
\text { reduction } \\
\%\end{array}$} & \multicolumn{4}{|c|}{ Setting time ( hour : minute) } & \multirow{2}{*}{$\begin{array}{l}\text { Cement } \\
\text { content } \\
(\mathrm{c} . \mathrm{c}) \\
\mathrm{kg} / \mathrm{m}^{3} \\
\end{array}$} & \multirow{2}{*}{$\begin{array}{c}\text { Limits } \\
\text { ESS1899-2006/1 }\end{array}$} \\
\hline & Result & Diff. & & Initial & Diff. & Final & Diff. & & \\
\hline Control mix (c) & 2.0 & --- & -..-- & $5: 05$ & -- & $7: 20$ & --- & \multirow{4}{*}{350} & \multirow{4}{*}{$\begin{array}{l}\text { For mixes containing } \\
\text { addition } \\
\text {-Water reduction: } \\
12 \% \text { at least } \\
\text {-Setting times: Diff. } \\
\text { about control mix: } \\
\text {-Initial setting } \\
\text { At. Least 1:30 } \\
\text {-Final setting } \\
\text { Not more } 6: 00 \text { later } \\
\text {-Air entraining } \\
\leq 2 \% \text { by volume about } \\
\text { control mix }\end{array}$} \\
\hline $1.5 \%$ [Addcrete BVS] & 2.8 & +0.8 & 16.7 & $8: 30$ & $3: 25$ & $10: 33$ & $3: 13$ & & \\
\hline $2.0 \%$ [Addcrete BVS] & 3.2 & +1.2 & 21.1 & 9:00 & $3: 55$ & $11: 42$ & $4: 22$ & & \\
\hline $2.5 \%$ [Addcrete BVS] & 3.8 & +1.8 & 25.0 & $9: 15$ & $4: 10$ & $12: 45$ & $5: 25$ & & \\
\hline
\end{tabular}


Shawky M. H. et al., Improvement of the concrete characteristics by using sugar industry wastes .....

\subsection{Hardened concrete test results}

\subsubsection{Compressive strength}

Table 11 contains the results of test for compressive strength for all mixtures with (VSW2016) additive at ages 7 days \& 28 days. Figures no. 3, 4 show the results of compressive strength for age 7 days \& 28 days. In general it was noticed that the values of compressive strength increase with (VSW2016) addition increases up to $2.5 \%$ for all cement contents according to (ESS 1988 - 1685) [ water reducing high rang and retarding] , the increase percentages after 7 days \& 28 days excess $115 \%$ \& $110 \%$ respectively . All admixture percentages at all cement contents corresponding with the specification requirements. It's that, there is an economy in cement content at least $15 \%$ at mixtures with (VSW2016) addition compare with control mix. Table no. 12 contains the results of test for compressive strength for mixture with $350 \mathrm{~kg} / \mathrm{m}^{3}$, using Addcrete BVS additive at age 7 days $\& 28$ days. Figures no. 5,6 shows the results of compressive strength for age 7 days \&28 days for mixture with $350 \mathrm{~kg} / \mathrm{m}^{3}$, using Addcrete BVS and (VSW2016). It was also noticed that the values of Compressive strength for mixture with $350 \mathrm{~kg} / \mathrm{m}^{3}$, using Addcrete BVS additive achieved early resistance at 7 days values higher than the using (VSW2016) additive .But achieved compressive strength at 28 days lower that the using (VSW2016) additive.

\section{Table 11.}

Results of compressive strength and drying shrinkage using (VSW2016)

\begin{tabular}{|c|c|c|c|c|c|c|c|}
\hline \multirow{2}{*}{$\begin{array}{l}\text { Type \& Percentage } \\
\text { of (VSW2016) } \\
\text { cement weight }\end{array}$} & \multicolumn{5}{|c|}{ Compressive strength (f) $\mathrm{kg} / \mathrm{cm}^{2}$, drying shrinkage $\%$} & \multirow{2}{*}{$\begin{array}{c}\text { Cement } \\
\text { content } \\
\text { (c.c) } \\
\mathrm{kg} / \mathrm{m}^{3}\end{array}$} & \multirow{2}{*}{$\begin{array}{c}\text { Limits } \\
\text { ESS1899- } \\
1 / 2006\end{array}$} \\
\hline & $\mathrm{f}_{\mathrm{C} 7}$ & $\begin{array}{c}\mathrm{f}_{\mathrm{C7}(\mathrm{Vsw} /} \\
\mathrm{f}_{67(\mathrm{c}) \%}\end{array}$ & $\mathrm{~F}_{\mathrm{C} 28}$ & $\begin{array}{c}f_{\mathrm{C} 28(\mathrm{Vsw} \gamma} \gamma \\
\mathrm{f}_{\mathrm{C} 28(\mathrm{c})} \%\end{array}$ & $\begin{array}{c}\text { Drying } \\
\text { shrimkage \% }\end{array}$ & & \\
\hline Control mix (c) & 164.34 & 100 & 257.4 & 100 & & \multirow{4}{*}{300} & \multirow{12}{*}{$\begin{array}{l}\text { For mixes } \\
\text { containing } \\
\text { addition } \\
\text { Comp. stre. } \\
\text { (7days) at least } \\
115 \% \text { than } \\
\text { control (ESS) } \\
\text { Comp.stre. } \\
\text { (28days) } \\
\text { at least } 110 \% \\
\text { than control } \\
\text { mix ( ESS ) }\end{array}$} \\
\hline $1.5 \%$ [VSW2016] & 224.5 & 137 & 312.0 & 121 & & & \\
\hline $2.0 \%$ [VSW2016] & 233.2 & 142 & 321.3 & 121 & & & \\
\hline $2.5 \%$ [VSW2016] & 276.1 & 168 & 340.7 & 132 & & & \\
\hline Control mix (c) & 170.49 & 100 & 317.5 & 100 & -2 & \multirow{4}{*}{350} & \\
\hline $1.5 \%$ [VSW2016] & 246.4 & 144 & 327.7 & 103 & -2.7 & & \\
\hline $2.0 \%$ [VSW2016] & 274.3 & 161 & 343.7 & 108 & -3 & & \\
\hline $2.5 \%$ [VSW2016] & 324.2 & 190 & 390.8 & 123 & -3.2 & & \\
\hline Control mix (c) & 239.3 & 100 & 353.40 & 100 & & \multirow{4}{*}{400} & \\
\hline $1.5 \%$ [VSW2016] & 303.3 & 1.268 & 393.0 & 111 & & & \\
\hline $2.0 \%$ [VSW2016] & 316.7 & 132 & 414.0 & 117 & & & \\
\hline $2.5 \%$ [VSW 2016$]$ & 318.0 & 133 & 416.5 & 118 & & & \\
\hline
\end{tabular}

Table 12.

Results of compressive strength and drying shrinkage for mixture with $350 \mathrm{~kg} / \mathrm{m}^{3}$ using Addcrete BVS additive.

\begin{tabular}{|c|c|c|c|c|c|c|}
\hline \multirow{2}{*}{$\begin{array}{c}\text { Type \& Percentage of } \\
\text { Adcrete BVS / cement } \\
\text { weight }\end{array}$} & \multicolumn{5}{|c|}{ Compressive strength $\left(f_{c}\right) \mathrm{kg} / \mathrm{cm}^{2}$, drying shrinkage $\%$} & \multirow{2}{*}{$\begin{array}{c}\text { Cement } \\
\text { content } \\
\mathrm{kg} / \mathrm{m}^{3}\end{array}$} \\
\hline & $\mathrm{f}_{\mathrm{C} 7}$ & $\begin{array}{l}\mathrm{f}_{\mathrm{C} 7(\mathrm{BVS})} \\
/ \mathrm{f}_{\mathrm{c} 7(\mathrm{c}) \%}\end{array}$ & $\mathrm{~F}_{\mathrm{C} 28}$ & $\begin{array}{c}\mathrm{f}_{\mathrm{C} 28(\mathrm{BVS})} / \\
\mathrm{f}_{\mathrm{c} 28(\mathrm{c}) \%}\end{array}$ & $\begin{array}{c}\text { Drying } \\
\text { shrinkage } \\
\%\end{array}$ & \\
\hline Control mix (c) & 170.49 & 100 & 317.5 & 100 & -2 & \multirow{4}{*}{350} \\
\hline $1.5 \%$ [Addcrete BVS ] & 294.3 & 173 & 322.1 & 101 & -2.4 & \\
\hline $2.0 \%$ [Addcrete BVS ] & 311.4 & 183 & 335.2 & 106 & -2.6 & \\
\hline $2.5 \%$ [Addcrete BVS ] & 331.7 & 195 & 355.5 & 112 & -2.8 & \\
\hline
\end{tabular}




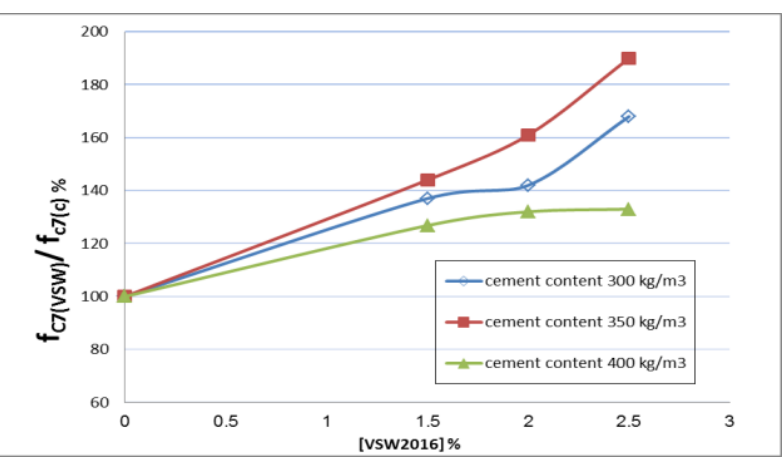

Fig. 3. Compressive strength at 7 days using (VSW2016).

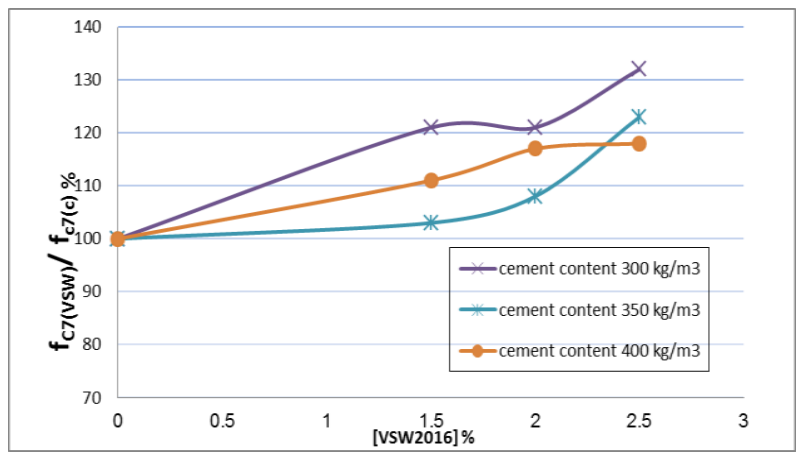

Fig. 4. Compressive strength at 28 days using (VSW2016).

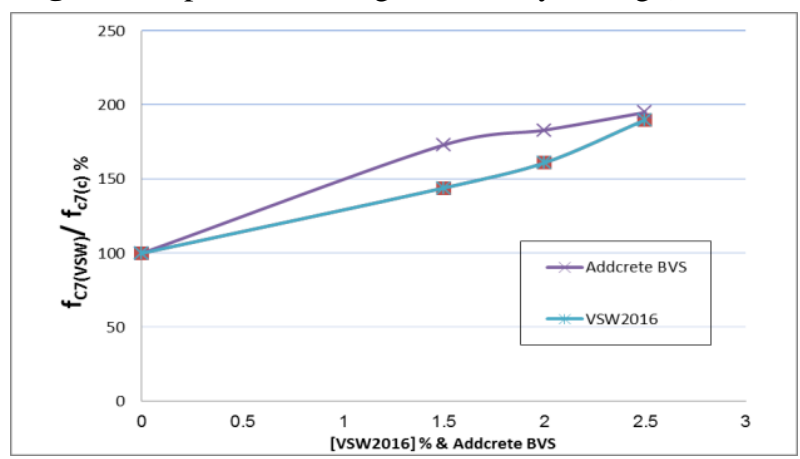

Fig. 5. Compressive strength at 7 days using BVS, (VSW2016) with C.C. $350 \mathrm{~kg} / \mathrm{m}^{3}$.

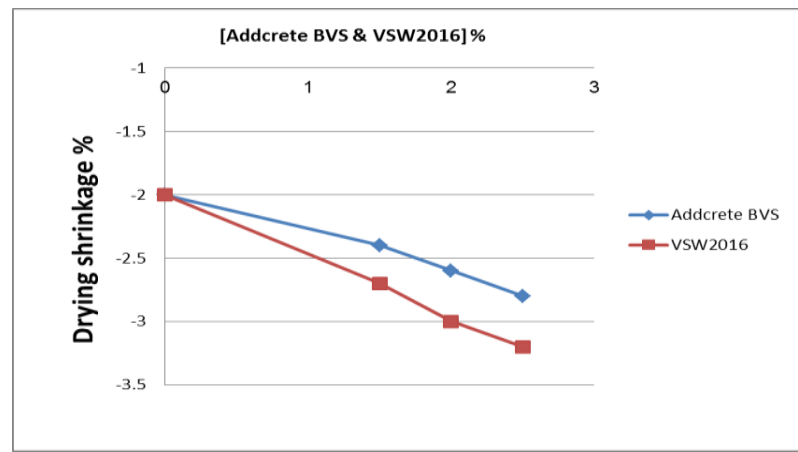

Fig. 6. Compressive strength at 28 days using BVS, (VSW2016) with $350 \mathrm{~kg} / \mathrm{m}^{3}$. 


\subsubsection{Drying shrinkage}

Tables no. $11 \& 12$ shows the results of drying shrinkage for both of (VSW2016) and addcrete BVS. Fig. no. 7 shows the results of drying shrinkage for both of using (VSW 2016) and addcrete BVS at cement content $350 \mathrm{~kg} / \mathrm{m}^{3}$, it is noticed that both of (VSW2016) and addcrete BVS reduce drying shrinkage. But the (VSW2016) is the better.

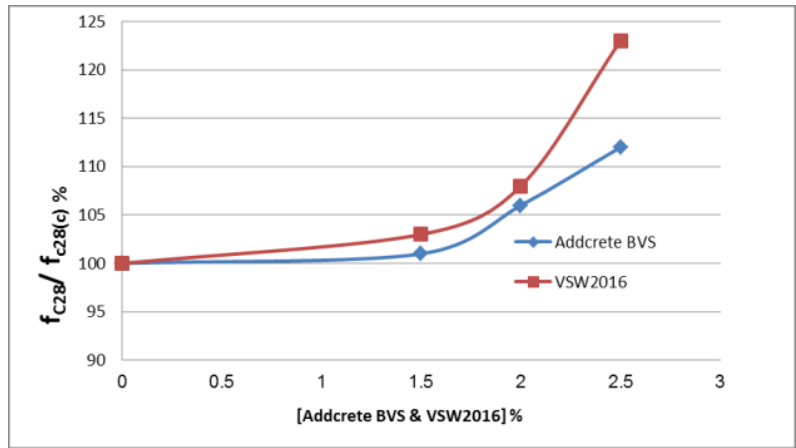

Fig. 7. Drying shrinkage using BVS, (VSW2016) with $350 \mathrm{~kg} / \mathrm{m}^{3}$.

\subsubsection{Indirect Tensile Strength}

\subsubsection{Splitting strength}

It is one of the types of the tension strength for concrete; it is used in evaluation of the shear strength of concrete. Table no.13 shows the results of tests for indirect tensile resistance for mixtures at age 28 days and fig no. 8 shows the results at age 28 days. It is clear that the result of splitting strength follows the results of tests for compressive strength from increasing trend. In general the [VSW2016] addition has caused a noticeable improvement in the results of the indirect tensile strength in comparison with control mixtures for all cement contents. Table no. 14 shows the results at age 28 day using addcrete BVS at cement content $350 \mathrm{~kg} / \mathrm{m}^{3}$ and the results are approximately similar.

\subsubsection{Flexural strength}

Flexural strength is the ability of element from ordinary concrete to resist the failure by flexural or the strength of cracks for reinforcement concrete elements. Table no.13 shows the results of tests for flexural strength of all mixtures at age 28 day. Fig no. 8 shows the results at age 28 day. It is clear that the effect of [VSW2016] addition on the flexural strength is approximately similar to it is effect on compressive strength from increasing trend. Table no. 14 shows the results at age 28 day using addcrete BVS at cement content $350 \mathrm{~kg} / \mathrm{m}^{3}$.

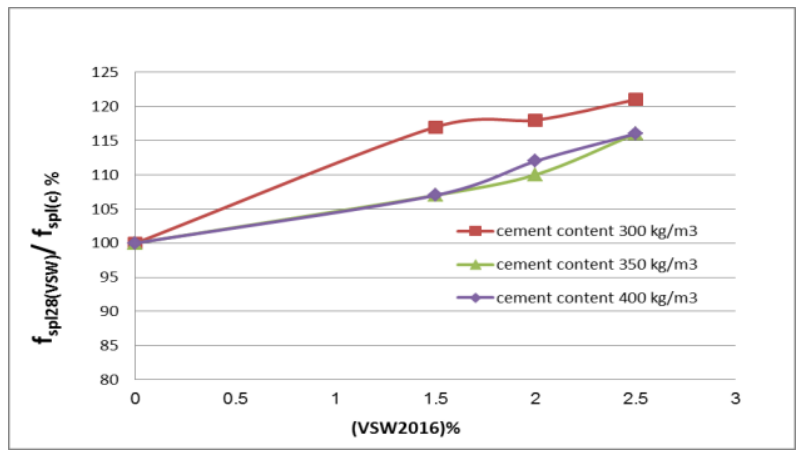

Fig. 8. Splitting tensile strength using (VSW2016). 
JES, Assiut University, Faculty of Engineering, Vol. 46, No. 2, March 2018, pp.142-159

Table 13.

Indirect tensile strengths tests at 28 days using (VSW2016) additon

\begin{tabular}{|c|c|c|c|c|c|c|c|}
\hline \multirow{3}{*}{$\begin{array}{c}\text { Type \& } \\
\text { Percentage of } \\
\text { (VSW2016) / } \\
\text { cement weight }\end{array}$} & \multirow{3}{*}{$\begin{array}{l}\text { Cement } \\
\text { content } \\
(\text { c.c }) \\
\mathrm{kg} / \mathrm{m}^{3}\end{array}$} & \multicolumn{6}{|c|}{ Indirect of tensile strength $\mathrm{kg} / \mathrm{cm}^{2}$} \\
\hline & & \multicolumn{3}{|c|}{ Splitting strength $\mathrm{f}_{\mathrm{spl}} \mathrm{kg} / \mathrm{cm}^{2}$} & \multicolumn{3}{|c|}{ Flexural strength $\mathrm{f}_{\mathrm{cr}} \mathrm{kg} / \mathrm{cm}^{2}$} \\
\hline & & $\mathrm{f}_{\text {spl28 }}$ & $\begin{array}{c}\mathrm{f}_{\mathrm{spl} 28(\mathrm{VSW})} / \\
\mathrm{f}_{\mathrm{spl}(\mathrm{c}) \%}\end{array}$ & $\begin{array}{c}\mathrm{f}_{\mathrm{c} 28(\mathrm{VSW})} \\
/ \mathrm{f}_{\mathrm{spl} 28}\end{array}$ & $\mathrm{f}_{\mathrm{cr} 28}$ & $\begin{array}{c}\mathrm{f}_{\mathrm{Cr} 28(\mathrm{VSW})} / \\
\mathrm{f}_{\mathrm{cr} 28(\mathrm{c}) \%}\end{array}$ & $\begin{array}{c}\mathrm{f}_{\mathrm{c} 28(\mathrm{VSW})} / \\
\mathrm{f}_{\mathrm{cr} 28}\end{array}$ \\
\hline Control mix (c) & \multirow{4}{*}{300} & 24.74 & 100 & 10.4 & 39.6 & 100 & 6.5 \\
\hline $\begin{array}{c}1.5 \% \\
{[V S W 2016]}\end{array}$ & & 28.90 & 117 & 10.8 & 47.0 & 119 & 6.64 \\
\hline $\begin{array}{c}2.0 \% \\
\text { [VSW2016] }\end{array}$ & & 29.20 & 118 & 11.0 & 51.0 & 129 & 6.3 \\
\hline $\begin{array}{c}2.5 \% \\
\text { [VSW2016] }\end{array}$ & & 29.90 & 121 & 11.4 & 55.0 & 139 & 6.16 \\
\hline Control mix (c) & \multirow{4}{*}{350} & 27.04 & 100 & 11.7 & 42.3 & 100 & 7.51 \\
\hline $\begin{array}{c}1.5 \% \\
\text { [VSW2016] }\end{array}$ & & 28.90 & 107 & 11.33 & 49.4 & 116 & 6.63 \\
\hline $\begin{array}{c}2.0 \% \\
\text { [VSW2016] }\end{array}$ & & 29.60 & 110 & 11.6 & 54.3 & 128 & 6.33 \\
\hline $\begin{array}{c}2.5 \% \\
\text { [VSW2016] }\end{array}$ & & 31.40 & 116 & 12.44 & 57.0 & 134 & 6.86 \\
\hline Control mix (c) & \multirow{4}{*}{400} & 27.60 & 100 & 12.8 & 48.5 & 100 & 7.29 \\
\hline $\begin{array}{c}1.5 \% \\
\text { [VSW2016] }\end{array}$ & & 29.30 & 106 & 13.4 & 50.4 & 104 & 7.8 \\
\hline $\begin{array}{c}2.0 \% \\
\text { [VSW2016] }\end{array}$ & & 31.10 & 113 & 13.3 & 55.1 & 114 & 7.51 \\
\hline $\begin{array}{c}2.5 \% \\
\text { [VSW2016] }\end{array}$ & & 31.90 & 116 & 13.0 & 57.4 & 118 & 7.26 \\
\hline
\end{tabular}

\section{Table 14.}

Indirect tensile strengths tests at 28 days using addcrete BVS with (c.c) $350 \mathrm{~kg} / \mathrm{m}^{3}$

\begin{tabular}{|c|c|c|c|c|c|c|c|}
\hline \multirow{3}{*}{$\begin{array}{c}\text { Type \& Percentage of } \\
\text { addcrete BVS / cement } \\
\text { weight }\end{array}$} & \multirow{3}{*}{$\begin{array}{l}\text { Cement } \\
\text { content } \\
(\mathrm{c} . \mathrm{c}) \\
\mathrm{kg} / \mathrm{m}^{3}\end{array}$} & \multicolumn{6}{|c|}{ Indirect of tensile strength $\mathrm{kg} / \mathrm{cm}^{2}$} \\
\hline & & \multicolumn{3}{|c|}{ Splitting strength $\mathrm{f}_{\mathrm{spl}} \mathrm{kg} / \mathrm{cm}^{2}$} & \multicolumn{3}{|c|}{ Flexural strength $\mathrm{f}_{\mathrm{cr}} \mathrm{kg} / \mathrm{cm}^{2}$} \\
\hline & & $\mathrm{f}_{\text {spl28 }}$ & $\begin{array}{c}\mathrm{f}_{\mathrm{spl} 28(\mathrm{BVS})} / \\
\mathrm{f}_{\mathrm{spl}(\mathrm{c}) \%}\end{array}$ & $\begin{array}{c}\mathrm{f}_{\mathrm{c} 28(\mathrm{BVS})} / \\
\mathrm{f}_{\mathrm{spl} 28}\end{array}$ & $\mathrm{f}_{\mathrm{cr} 28}$ & $\begin{array}{c}\mathrm{f}_{\mathrm{Cr} 28(\mathrm{BVS})} / \\
\mathrm{f}_{\mathrm{cr} 28(\mathrm{c}) \%}\end{array}$ & $\begin{array}{c}\mathrm{f}_{\mathrm{c} 28(\mathrm{BVS}} / \\
\mathrm{f}_{\mathrm{cr} 28}\end{array}$ \\
\hline Control mix (c) & \multirow{4}{*}{350} & 27.04 & 100 & 13.21 & 42.3 & 100 & 7.51 \\
\hline $1.5 \%$ [Addcrete BVS ] & & 28.60 & 106 & 11.26 & 52.2 & 124 & 6.17 \\
\hline $2.0 \%$ [Addcrete BVS ] & & 29.20 & 108 & 11.48 & 57.8 & 137 & 5.8 \\
\hline $2.5 \%$ [Addcrete BVS ] & & 30.10 & 113 & 11.81 & 61.7 & 146 & 5.76 \\
\hline
\end{tabular}




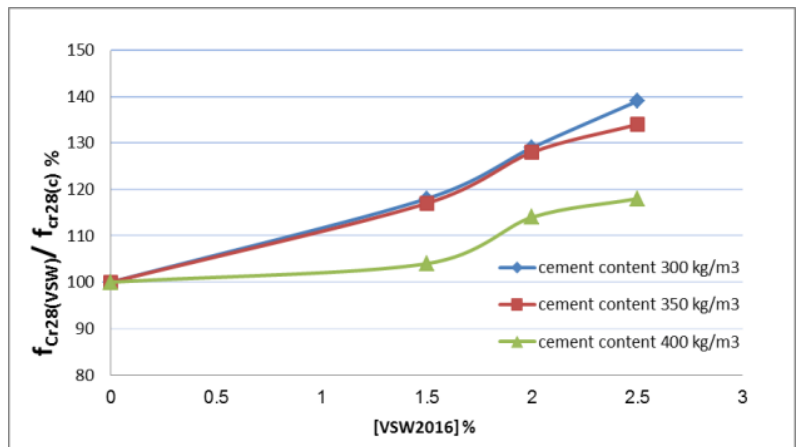

Fig. 9. Flexural of tensile strength using (VSW2016).

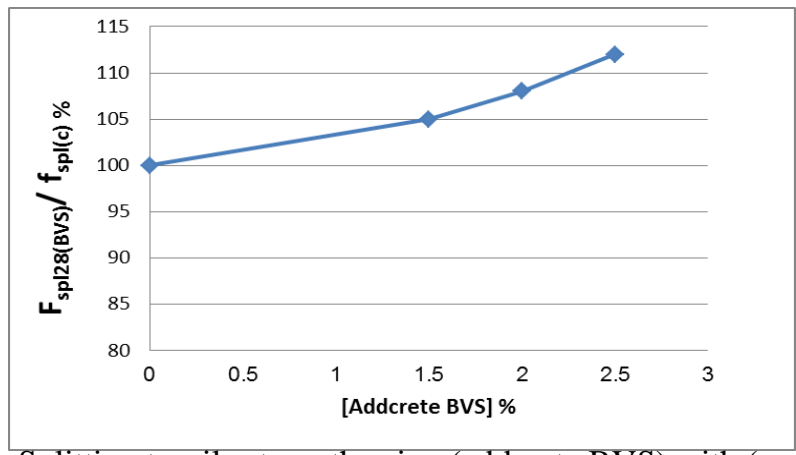

Fig. 10. Splitting tensile strength using (addcrete BVS) with (c.c) $350 \mathrm{~kg} / \mathrm{m}^{3}$

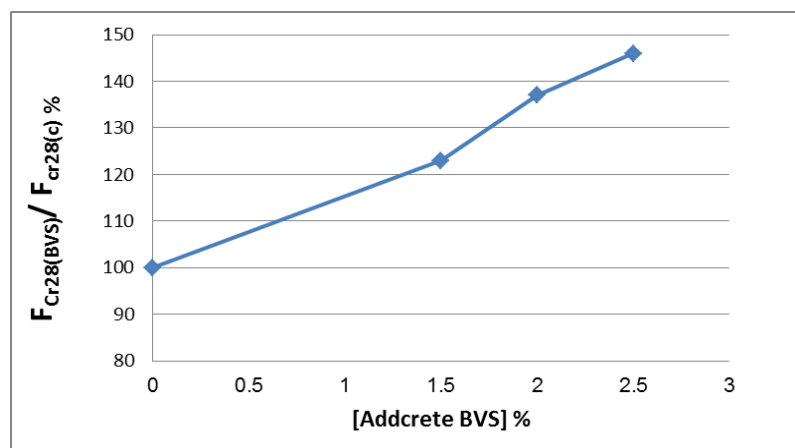

Fig. 11. Flexural of tensile strength using (addcrete BVS) with (c.c) $350 \mathrm{~kg} / \mathrm{m}^{3}$

\section{Conclusions}

The current study is concerning with the effect of adding [VSW2016] to the concrete properties for both fresh and hardened states, concerning of maximizing the benefits from the vinasse liquid, which is produced in ESIIC, this due to the fact that vinasse is by a-product from fermentation and distillation of the molasses liquid which is a sugar industry product .

The current research focused on the using of concentrated vinasse (35\%) as a concrete super plasticizer admixture, this is by add and mix it with Sodium Naphthalene Formaldehyde, water and mirgal V6 to make [VSW2016]addition. The experimental work has been carried out by casting and testing of concrete mixtures in three different cement contents $\left[300,350,400 \mathrm{~kg} / \mathrm{m}^{3}\right]$ to produce some arrangements covering a wide range of applications, also the [VSW2016] addition has been added in three different percentages $(1.5 \%, 2 \%, 2.5 \%)$ from cement weight in order to compare the effect of [VSW2016] addition on the concrete mixtures and specify some of basic properties in both 
fresh and hardened states. Also using commercial admixture like addcrete BVS at cement content $350 \mathrm{~kg} / \mathrm{m}^{3}$ to compare with the effect of (VSW 2016). Accordance with ESS18991/ 2006 the test results indicated till the age 28 days as the following:

1-[VSW2016] addition has achieved that reducing of the mixture water content with the plastic concrete consistency, the water reduce from $12.57 \%$ to $21.1 \%$ at cement content $300 \mathrm{~kg} / \mathrm{m}^{3}$, from $16.7 \%$ to $21.1 \%$ at cement content $350 \mathrm{~kg} / \mathrm{m}^{3}$ and from 23.7 $\%$ to $30.5 \%$ at cement content $400 \mathrm{~kg} / \mathrm{m}^{3}$. It's clear from these results the efficient of [VSW2016] addition in improving the concrete consistency and increases workability, and the results accordance with specification requirements. Also using addcrete BVS addition accordance with ESS1899-1/ 2006 in terms of water reducing.

2- The [VSW2016] addition achieves a noticeable delay in the initial and finally setting times at all mixtures associated with specification requirements. Also using addcrete BVS addition with cement content $350 \mathrm{~kg} / \mathrm{m}^{3}$ achieves a noticeable delay in the initial and finally setting times at all mixtures associated with specification requirements.

3- Air - entraining for test mixtures which contain both of [VSW2016] addition and addcrete BVS addition with cement content $350 \mathrm{~kg} / \mathrm{m}^{3}$ achieves the specification requirements.

4-Compressive strength for concrete improves by using [VSW2016] addition as a direct result for reducing of mixing water content and the maximum increasing in compressive strength has been achieved at $2.5 \%$ from cement content at all mixtures with cement contents $300,350,400 \mathrm{~kg} / \mathrm{m}^{3}$. Also for test mixtures which contain addcrete BVS addition with cement content $350 \mathrm{~kg} / \mathrm{m}^{3}$, the maximum increasing in compressive strength has been achieved at $2.5 \%$ from cement content. There is an economy in cement content at least $15 \%$ at mixtures with (VSW2016) addition compare with control mix.

5-The effect of [VSW2016] addition on the results of indirect tensile strengths (splitting, flexural) are approximately similar with effect on compressive strength from increasing trend. Also for test mixtures which contain addcrete BVS addition are approximately similar with effect on compressive strength from increasing trend.

6- The (VSW2016) addition reduce drying shrinkage as a direct result for reducing of mixing water content and delay setting time at cement content $350 \mathrm{~kg} / \mathrm{m}^{3}$. Also addcrete BVS addition reduce drying shrinkage but with little degree than (VSW 2016) addition.

7 - It is noticed clearly that all results of fresh and hardened concrete mixtures using (VSW 2016) addition are better than using addcrete BVS addition.

Therefore the optimum dose of the suggested admixture [VSW2016] addition at which maximum values of compressive and indirect tensile (splitting and Flexural) strengths of concrete specimens at hardened concrete, is determined and equals $2.5 \%$ from cement content and accordance with specification requirements.

\section{REFERENCES}

[1] Omar F. , Said H. , Amal B. and Shawky M.H " Using sugar industry wastes ( Vinasse ) as a plasticizer concrete admixture enhancing durability consideration " International conference on innovation building materials .Egypt (HBRC) 2014

[2] Hasan Y. and Baris A. " Usage of molasses in concrete as a water reducing and retarding admixture " Indian journal of Engineering \& materials sciences 19 pp 421-426, Istanbul technical university, Turkey, 2012. 
[3] Somawanshi, S.P., Ansari, U.S and Karale, S.A. "Effect of molasses in concrete as a water reducing and time retarding admixture " International journal of recent scientific research vol.7 pp 13417- 134421(2016) .

[4] Neville, A .M. "Properties of concrete "Fourth international education, Dorling Kindersley, Newdelhi, India 2006.

[5] Neville, A .M. and Brooks "Concrete technology "Mulaysia Prentice Hall 2004.

[6] Ravin a, D, and I, Soroka, "Research on Concrete in Hot Environments at the National Building Research Institude" ACI SP139, pp107-127.1993.

[7] Sherif A. M. Khafaga "Concrete using local materials for constructing projects at Toshka" MSC thesis, Ain Shams University 2003.

[8] Collepardi M "Admixtures used to enhance placing characteristics of concrete, cement and concrete composites" Vol. 20,pp-103-112,1998.

[9] A.Megahed A., F.K. Abd EL - Sayed and H.M. Soghair "Effect of super plasticizers on concrete characteristics " Journal of engineering sciences, Assiut university, pp 1-24 July, 1986.

[10] Sayed M.A.B, Tark A.E "Properties of concrete mixes containing blended cements with different type's chemical admixtures" MSC thesis. Helwan Univ. 2013.

[11] Dinesh Kumar, Ravi Kumar and Mahapara Abbass "Study the effect of coal bottom ash on partial replacement of fine aggregate in concrete with sugarcane molasses as an admixture" International journal of recent scientific research and education vol.4 pp. 5355 - 5362. (2016).

[12] M.Dheenandhayalan, G.Suvetha, D.Monica, Parvath S.Shenoi and R.Dhanasekaran "Effect of sugarcane juice in concrete by partial replaced coarse aggregate and silica fume in fine aggregate" International journal of intelligence research vol.7 pp. 976 - 985. (2016).

[13] Amazial, W.O and Wmocent,K "Sugarcane juice as a retarding admixture in concrete production" Global journal of engineering research No 14 pp. 17 - 25. (2015).

[14] Directory of laboratory tests for concrete material (ECP 203-2007) 


\section{تحسين خواص الخرسانة باستخدام مخلفات صناعة السكر (الفيناس)}

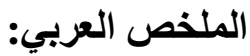

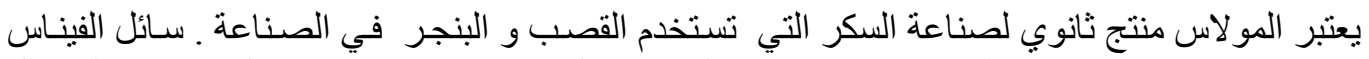

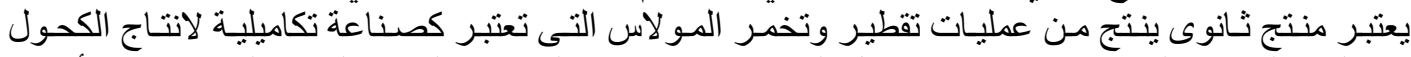

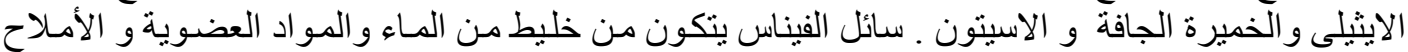

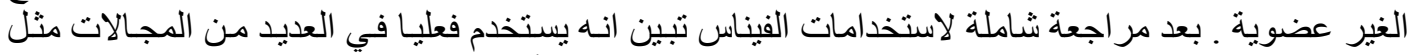

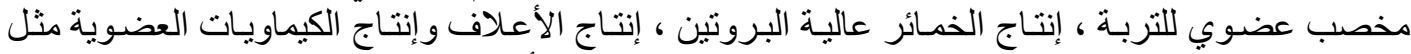

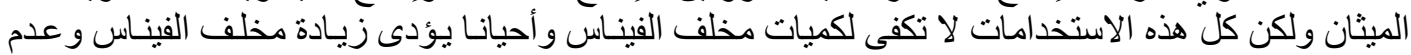

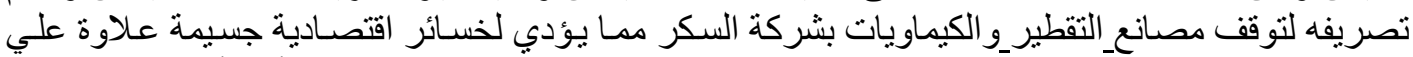

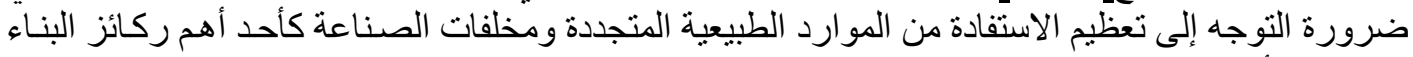

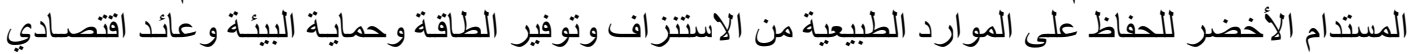

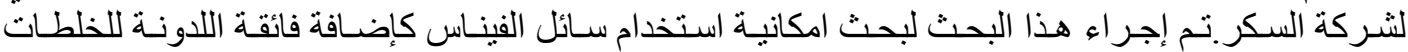

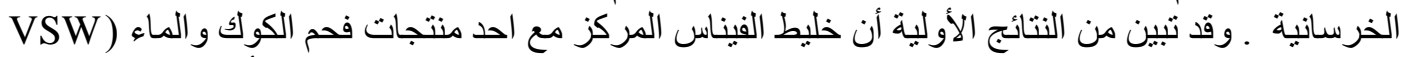

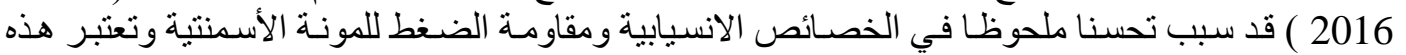

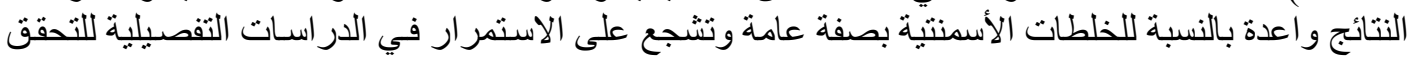
من كفاءة استخدام مادة ( VSW 2016 ) في التطبيقات المختلفة لأعمال البناء و التشييد الأنيد

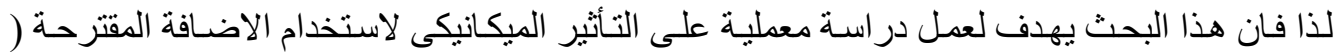

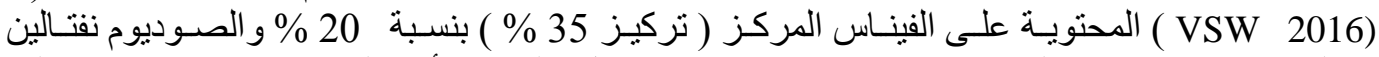

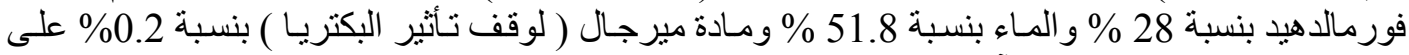
خواص الخرسانة علي النحو الآتي :-

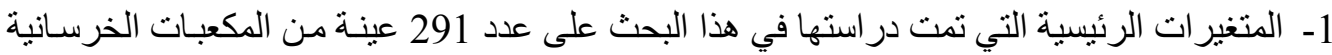

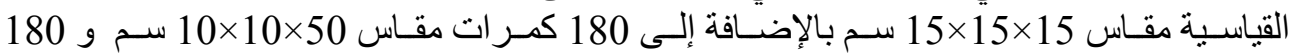
اسطو انة مقاس طول 30سم وقطر 15 الفر 15 سم هي:ا- بـ بدون إضافات كعينة للتحكم و المقارنة

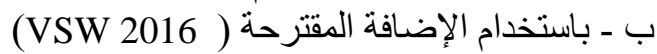

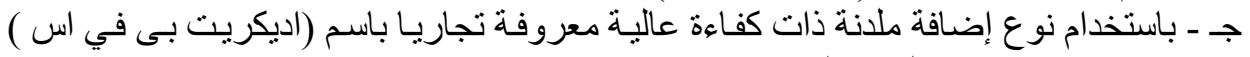

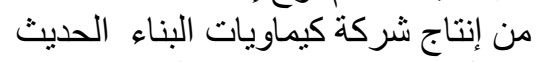

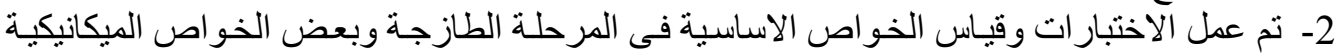

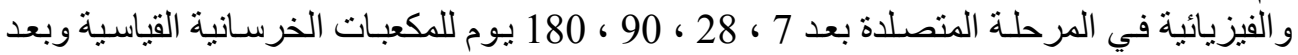

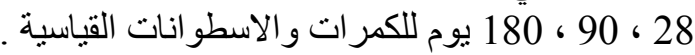
3- تم قياس بعض خصائص الديمومة للمكعبات الخرسانية بعد وصولة لهابل لمقاومة كافية عند عمر 28 يوم

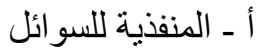

ب ـ التدهور في مقاومة الضغط ( الفقد فى المقاومـة) وتدهور الطبقات السطحية و التغيير في لون

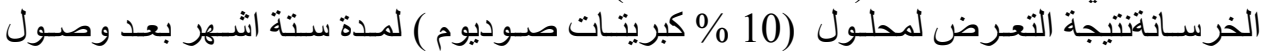

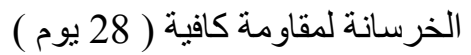

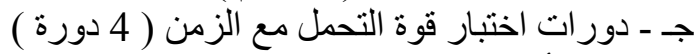

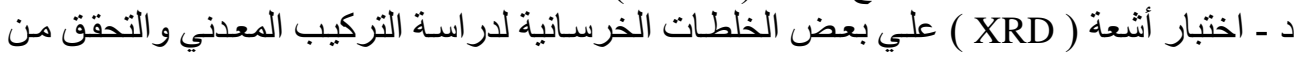

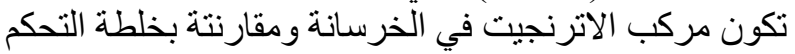
4- اختبار ات تعيين الخواص الكيميائية 
Shawky M. H. et al., Improvement of the concrete characteristics by using sugar industry wastes .....

أـ اختبـار ات كيميائيـة علي سـائل (VSW 2016) لتحديد الأس الهيدروجيني ومحتوي الكبريتـات

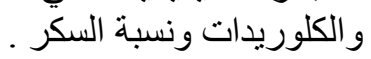

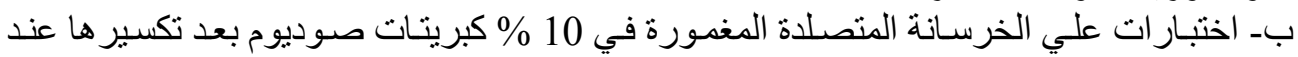

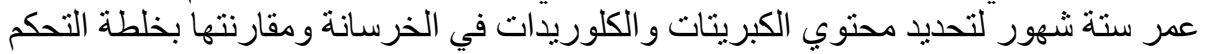

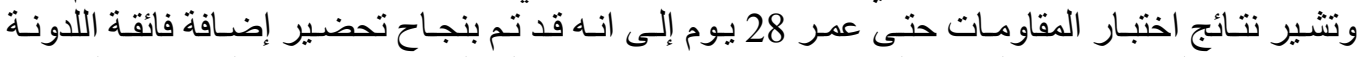

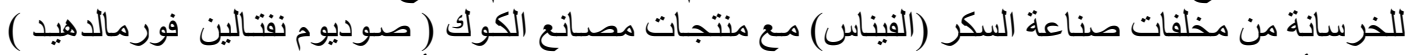

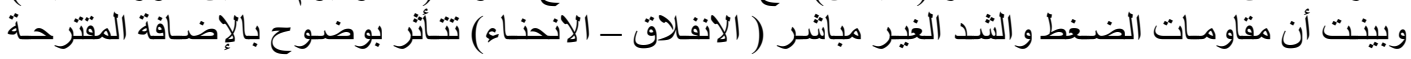

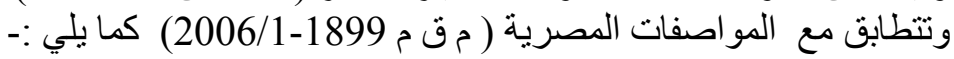

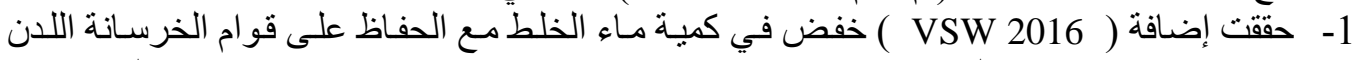

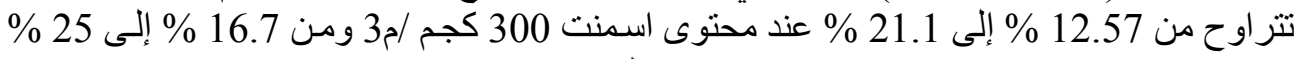

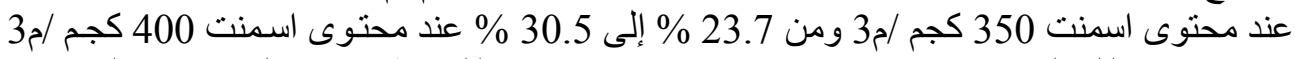

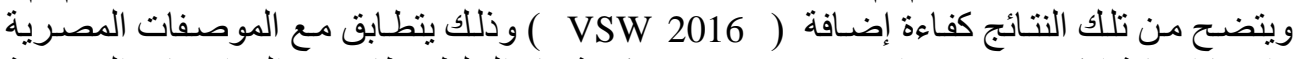
و وايضا اضافة ادكريت بى فى اس حققت خفض فى كمية ماء الخلط يتطابق مع المو اصفات المصنس الصرية

2- إضـافة ( 2016 VSW ) تحقق تأخير ملحوظ فى زمنى الثـك الابتدائى و النهائى يفى بمتطلبـات

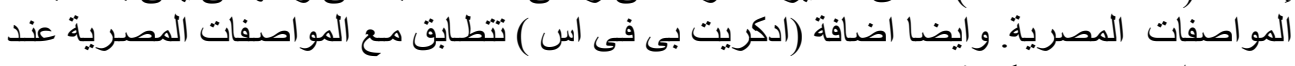

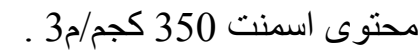

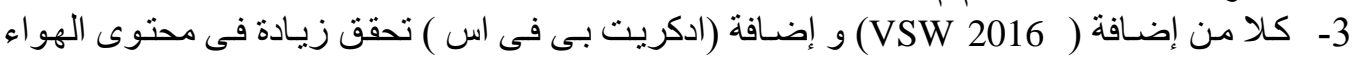

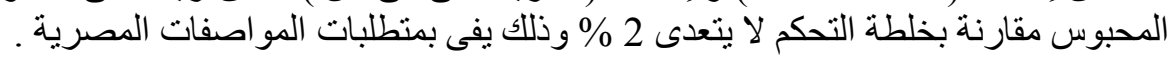

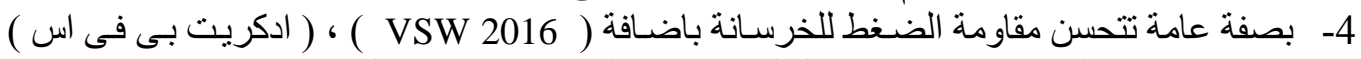

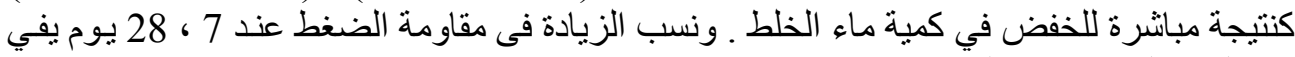

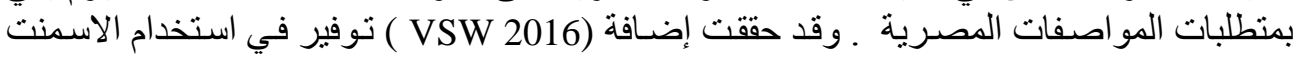

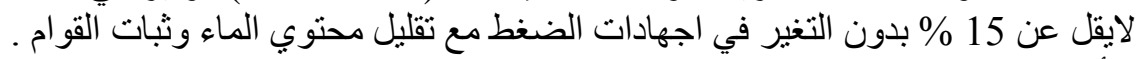

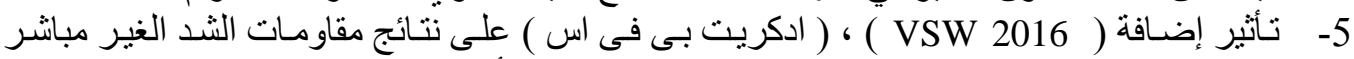

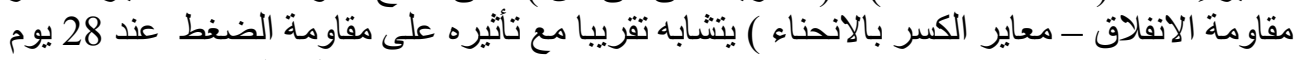

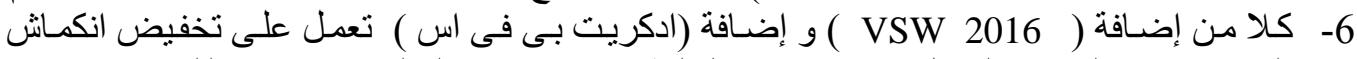

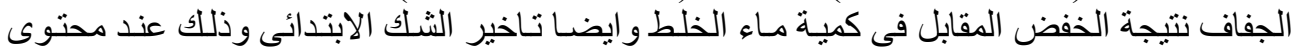

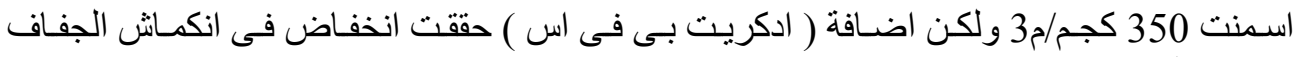

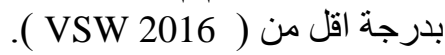

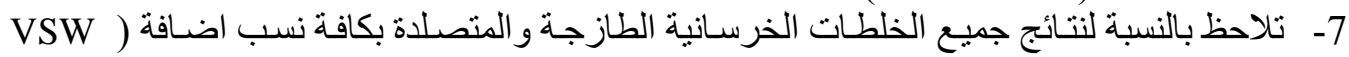

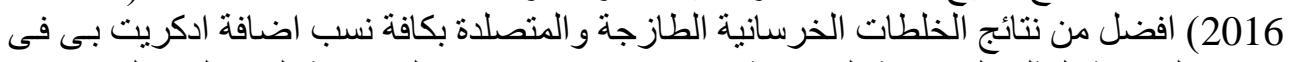

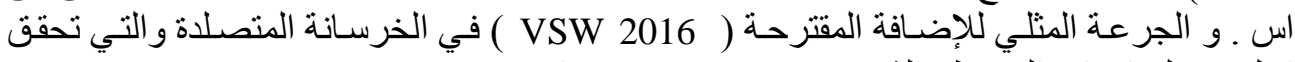
اعلي قيم لمقاومات الضغط وعة الثيد هي 2.5 \% من وزن الاسمنت. 